Proc. Indian Acad. Sci. (Chem. Sci.), Vol. 106, No. 1, February 1994, pp. 37-43.

(C) Printed in India.

\title{
Organometallic chemistry of diphosphazanes. Part IX: Syntheses and spectroscopic studies of molybdenum and tungsten tetracarbonyl complexes of unsymmetrical diphosphazanes
}

\author{
R P KAMALESH BABU and S S KRISHNAMURTHY* \\ Department of Inorganic and Physical Chemistry, Indian Institute of Science, Bangalore \\ 560012 , India \\ MS received 11 October 1993

\begin{abstract}
The unsymmetrical diphosphazanes $X_{2} P N\left(P^{i}\right) P Y Y^{\prime}(1 a-1 h)\left\{X=P h, Y Y^{\prime}=O_{2}\right.$ $\mathrm{C}_{6} \mathrm{H}_{4}$ (1a) or $\mathrm{YY}^{\prime}=\mathrm{O}_{2} \mathrm{C}_{12} \mathrm{H}_{8}(1 \mathrm{~b}) ; \mathrm{X}=\mathrm{Ph}, \mathrm{Y}=\mathrm{Ph}, \mathrm{Y}^{\prime}=\mathrm{OC}_{6} \mathrm{H}_{4} \mathrm{Me}-4$ (1c), $\mathrm{OC}_{6} \mathrm{H}_{4} \mathrm{Br}-4$ (1d). $\mathrm{OC}_{6} \mathrm{H}_{3} \mathrm{Me}_{2}-\underline{3}, \underline{5}(\underline{\mathrm{le}}), \mathrm{OC}_{3} \mathrm{H}_{4} \mathrm{~N}-\underline{2}$ (1f), $\mathrm{N}_{2} \mathrm{C}_{3} \mathrm{HMe}_{2}-\underline{3}, \underline{5}$ (1g) or $\left.\mathrm{Cl}(\underline{\mathrm{lh}})\right\}$ react with $\left[\mathrm{M}(\mathrm{CO})_{4}\left(\mathrm{NHC}_{5} \mathrm{H}_{10}\right)_{2}\right](\mathrm{M}=\mathrm{Mo}, \mathrm{W})$ to yield the cis-chelate complexes [M(CO) $\}_{4}\left\{\mathrm{X}_{2} \mathrm{PN}\left(\mathrm{Pr}^{\prime}\right)\right.$ $\left.{ }^{P Y Y^{\prime}} ;\right]\{M=M o(\underline{2 a}-\underline{2 h}) ; M=W(3 f, 3 \mathrm{~g})\}$. These complexes have been characterized by ${ }^{1} \mathrm{H},{ }^{3} \mathrm{P}$ and ${ }^{13} \mathrm{C} \mathrm{NMR}$ and IR spectroscopic studies.
\end{abstract}

Keywords. Unsymmetrical diphosphazane ligands; group 6 carbonyl complexes.

\section{Introduction}

Diphosphazanes have attracted considerable attention in recent years as "short-bite" ligands in transition metal organometallic chemistry (King 1980; Mague and Lin 1992; Balakrishna et al 1993, 1994; Field et al 1993; Rossi et al 1993). However, studies with unsymmetrically substituted diphosphazanes are sparse (Colquhoun and McFarlane 1977; Babu et al 1991, 1993). We had earlier established a correlation between the ${ }^{31} \mathrm{P}$ NMR chemical shifts of metal carbonyl complexes of the type cis- $\left[\mathrm{Mo}(\mathrm{CO})_{4}\left\{\mathrm{X}_{2} \mathrm{PN}(\mathrm{R}) \mathrm{PX}_{2}\right\}\right]$ and the $\pi$-acceptor ability of the phosphorus centres (Balakrishna et al 1990). In order to extend the validity of the correlation, we have synthesized group 6 metal-tetracarbonyl complexes of a series of unsymmetrically substituted diphosphazanes of the type cis-[M(CO) $\left.{ }_{4}\left\{\mathrm{X}_{2} \mathrm{PN}\left(\mathrm{Pr}^{\mathrm{i}}\right) \mathrm{PYY}^{\prime}\right\}\right]$ and characterised them by IR and NMR spectroscopy. The results of these studies are presented here. These unsymmetrically substituted diphosphazanes offer an advantage in that the two-bond $\mathbf{P}-\mathbf{P}$ coupling constants in the ligands as well as in the complexes can be directly measured from their ${ }^{31} \mathrm{P}$ NMR spectra.

\section{Experimental details}

All manipulations were carried out under an atmosphere of dry dinitrogen using standard Schlenk-tube technique (Shriver and Drezdzon 1986). Solvents were purified

* For correspondence

For Part VIII see, Babu et al (1993) 


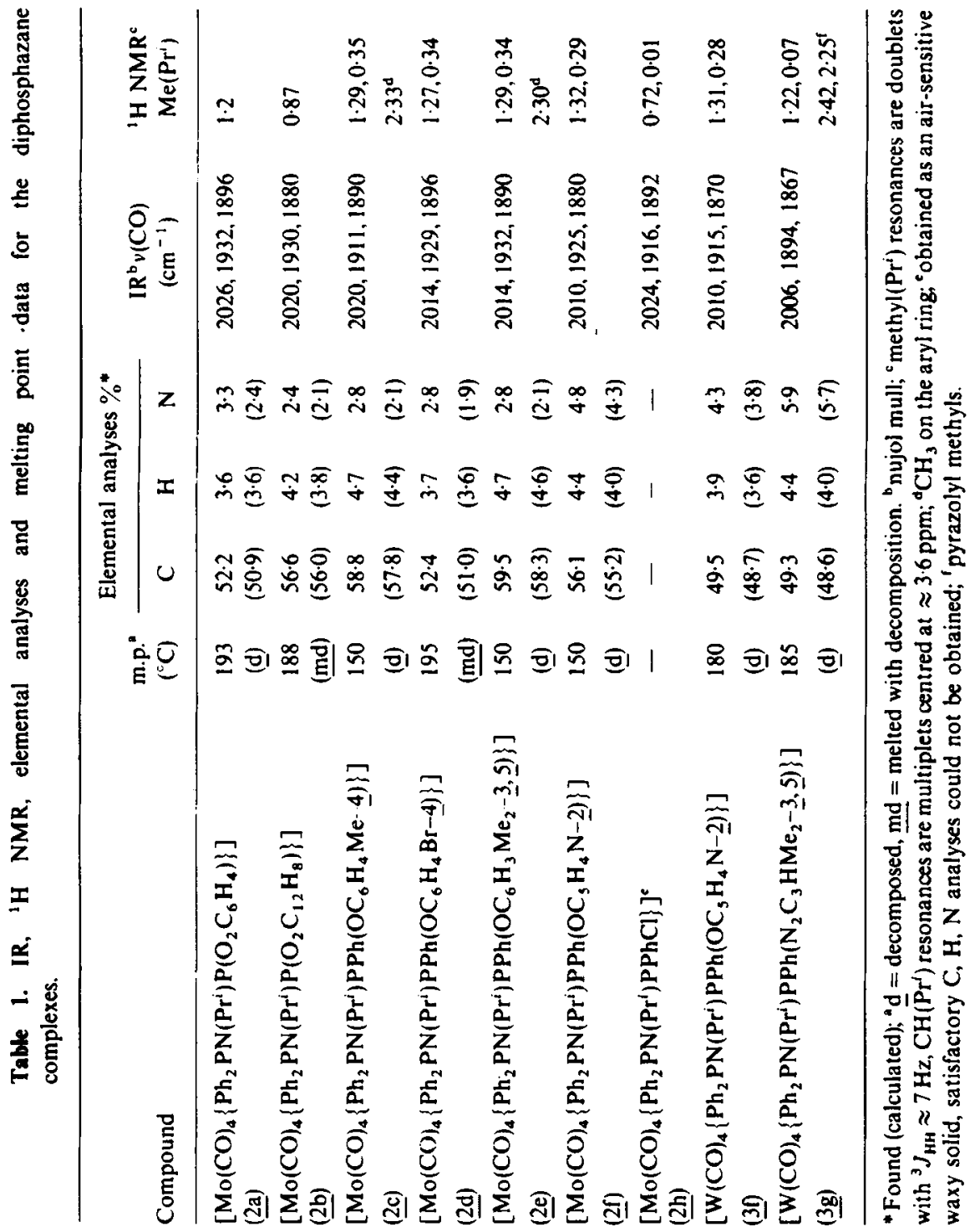


by standard methods. IR, and NMR spectra were recorded as reported previously (Babu et al 1993). C, H, N, analyses were carried out with a Heraeus CHN-O Rapid instrument. The diphosphazane ligands $(\underline{1 c},-1 \mathrm{f})$ were prepared by the reaction $\mathrm{Ph}_{2} \mathrm{PN}\left(\mathrm{Pr}^{\mathrm{i}}\right) \mathrm{PPhCl}$ (Cross et al 1976) with the corresponding phenol or secondary amine in boiling benzene in the presence of triethylamine (Babu, unpublished results). The diphosphazane (1a) was prepared as reported earlier (Babu et al 1991); diphosphazane (1b) was prepared in a similar manner (Babu, unpublished results). The precursor complex $\left[\mathrm{Mo}(\mathrm{CO})_{4}\left(\mathrm{NHC}_{5} \mathrm{H}_{10}\right)_{2}\right]$ was prepared by a published procedure (Darensbourg and Kump 1978).

\subsection{Preparation of cis- $\left[\mathrm{Mo}(\mathrm{CO})_{4}\left\{X_{2} P N\left(\operatorname{Pr}^{\mathrm{i}}\right) P Y Y^{\prime}\right\}\right](\underline{2 a}-\underline{2 h})$}

A mixture of cis-[Mo(CO) $\left.{ }_{4}\left(\mathrm{NHC}_{5} \mathrm{H}_{10}\right)_{2}\right]\left(5 \times 10^{-4} \mathrm{~mol}\right)$ and the diphosphazane ligand $\left(5 \times 10^{-4} \mathrm{~mol}\right)$ was dissolved in $25 \mathrm{ml}$ of dichloromethane and the solution was stirred for $30 \mathrm{~min}$. The resultant solution was filtered through silica gel and the solvent evaporated under reduced pressure. Crystallisation of the residue from a dichloromethane-petrol mixture (1:1), yielded the tetracarbonyl complex as a pale yellow solid. Yield $80-90 \%$.

\subsection{Preparation of cis- $\left[W(C O)_{4}\left\{X_{2} P N\left(P r^{j}\right) P Y Y^{\prime}\right\}\right](\underline{3 f}, \underline{3 g})$}

The procedure is similar to that of the molybdenum complex. In this case, the reaction mixture was heated under reflux for $3 \mathrm{~h}$. Yield $75-80 \%$.

The analytical and spectroscopic data are summarised in tables 1-3.

Table 2. ${ }^{13} \mathrm{C}\left\{{ }^{1} \mathrm{H}\right\}$ NMR data (carbonyl resonances only) for some diphosphazane complexes".

\begin{tabular}{|c|c|c|}
\hline \multirow[b]{2}{*}{ Diphosphazane complex } & \multicolumn{2}{|c|}{${ }^{13} \mathrm{C}$ NMR values } \\
\hline & $\delta(\mathrm{ppm})$ & ${ }^{2} J_{\mathrm{PC}}(\mathrm{Hz})$ \\
\hline $\begin{array}{l}{\left[\mathrm{Mo}(\mathrm{CO})_{4}\left\{\mathrm{Ph}_{2} \mathrm{PN}\left(\mathrm{Pr}^{i}\right) \mathrm{PPh}\left(\mathrm{OC}_{6} \mathrm{H}_{4} \mathrm{Me}-4\right)\right\}\right]} \\
(\underline{2 \mathrm{c})}\end{array}$ & $\begin{array}{l}218 \cdot 6(d d) \\
218 \cdot 3(d d) \\
213 \cdot 0(t) \\
208 \cdot 1(t)\end{array}$ & $\begin{array}{l}25 \cdot 0,10 \cdot 5 \\
30 \cdot 5,10 \cdot 0 \\
8 \cdot 1 \\
9 \cdot 0\end{array}$ \\
\hline $\begin{array}{l}{\left[\mathrm{Mo}(\mathrm{CO})_{4}\left\{\mathrm{Ph}_{2} \mathrm{PN}\left(\mathrm{Pr}^{i}\right) \mathrm{PPh}\left(\mathrm{OC}_{6} \mathrm{H}_{4} \mathrm{Br}-4\right)\right\}\right]} \\
(\underline{2 \mathrm{~d}})\end{array}$ & $\begin{array}{l}218 \cdot 4(d d) \\
217 \cdot 8(d d) \\
212 \cdot 7(t) \\
208 \cdot 2(t)\end{array}$ & $\begin{array}{l}25 \cdot 5,100 \\
300,9.5 \\
8.5 \\
10-0\end{array}$ \\
\hline $\begin{array}{l}{\left[\mathrm{Mo}(\mathrm{CO})_{4}\left\{\mathrm{Ph}_{2} \mathrm{PN}\left(\mathrm{Pr}^{i}\right) \mathrm{PPh}\left(\mathrm{OC}_{6} \mathrm{H}_{3} \mathrm{Me}_{2}-\underline{3}, 5\right)\right\}\right]} \\
(\underline{2 \mathrm{e}})\end{array}$ & $\begin{array}{l}220 \cdot 4(t) \\
219 \cdot 9(d d) \\
215 \cdot 0(t) \\
209 \cdot 6(t)\end{array}$ & $\begin{array}{l}15.0 \\
15.0,11 \cdot 6 \\
80 \\
9.7\end{array}$ \\
\hline $\begin{array}{l}{\left[\mathrm{Mo}(\mathrm{CO})_{4}\left\{\mathrm{Ph}_{2} \mathrm{PN}\left(\mathrm{Pr}^{i}\right) \mathrm{PPh}\left(\mathrm{N}_{2} \mathrm{C}_{3} \mathrm{HMe}_{2}-\underline{3}, 5\right)\right\}\right]} \\
(\underline{\mathrm{gg}})^{\mathrm{b}}\end{array}$ & $\begin{array}{l}219 \cdot 1(d d) \\
218 \cdot 1(d d) \\
214 \cdot 4(t) \\
207 \cdot 2(t)\end{array}$ & $\begin{array}{cc}25 \cdot 5, & 10 \cdot 0 \\
29 \cdot 0, & 9 \cdot 9 \\
9 \cdot 0 & \\
8 \cdot 0 & \end{array}$ \\
\hline
\end{tabular}

- Recorded at 50.32 MHz, internal standard TMS; 'Babu et al 1993 dd - doublet of doublets; $t$ - triplet 


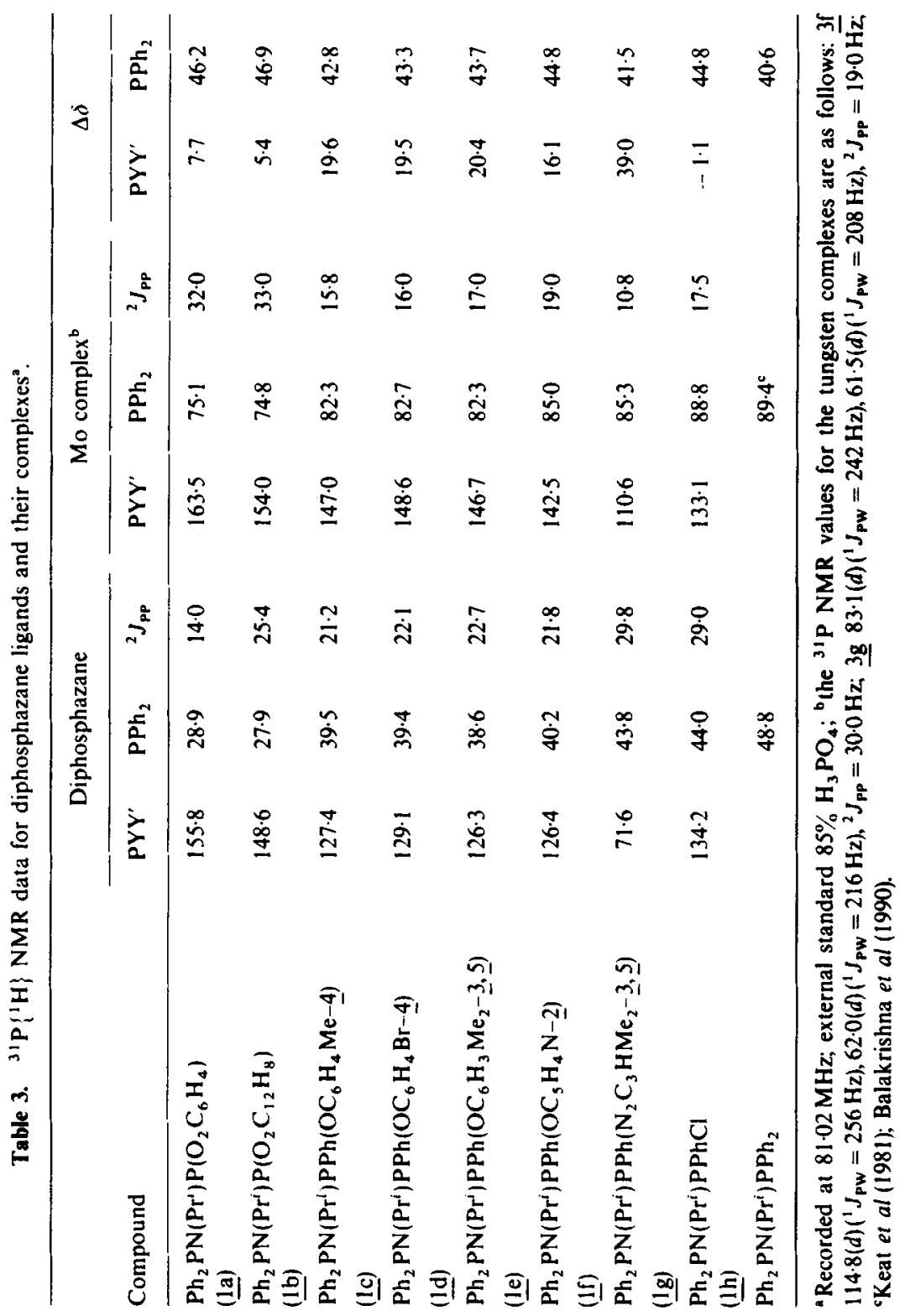




\section{Results and discussion}

Treatment of cis- $\left[\mathrm{M}(\mathrm{CO})_{4}\left(\mathrm{NHC}_{5} \mathrm{H}_{10}\right)_{2}\right](\mathrm{M}=\mathrm{Mo}, \mathrm{W})$ with an equimolar quantity of the unsymmetrical diphosphazane in dichloromethane yields the chelate complexes cis- $\left[\mathrm{M}(\mathrm{CO})_{4}\left\{\mathrm{X}_{2} \mathrm{PN}\left(\mathrm{Pr}^{\mathrm{i}}\right) \mathrm{PYY}^{\prime}\right\}\right]$ (scheme 1). The molybdenum complexes are readily formed within $10 \mathrm{~min}$ at room temperature, whereas the formation of the tungsten complexes requires the heating of the reaction mixture under reflux for three hours. The presence of an excess of the diphosphazane ligand also favours the formation of cis-chelate complexes.

The infra-red spectra of these complexes exhibit three strong $v_{\mathrm{CO}}$ absorptions in the range 2030 to $1865 \mathrm{~cm}^{-1}$ (table 1), characteristic of an $\mathrm{M}(\mathrm{CO})_{4}$ moiety bonded to strong $\pi$-acceptor ligands such as $\mathrm{MeN}\left(\mathrm{PF}_{2}\right)_{2}$ (King and Lee 1982; Cotton and Kraihanzel 1962). These values are in the range observed for similar type of diphosphazane complexes (Balakrishna et al 1990).

The ${ }^{1} \mathrm{H}$ NMR spectra for the complexes $2 \mathrm{a}$ and $2 \mathrm{~b}$ display a doublet for the methyl protons of the isopropyl group (table 1 ). These protons are shielded by $\sim 0.5 \mathrm{ppm}$

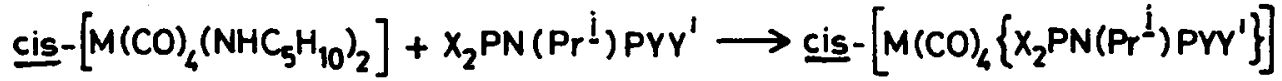

$$
\begin{aligned}
& \underline{1 a}-\underline{1 h} \\
& M=M_{0}, \underline{2 a}-\underline{2 h} \\
& M=W, \underline{3 f}, \underline{3 g} \\
& \text { 1a, 2a: } \quad x=P h, Y y^{\prime}=\stackrel{-0}{-0 O O} \\
& \text { 1b, 2b: } x=P h, Y y^{\prime}=\underbrace{0}_{0} \\
& \text { Ic, 2c : X }=\mathrm{Ph}, \mathrm{Y}=\mathrm{Ph}, \mathrm{Y}^{\prime}=-\mathrm{OC}_{6} \mathrm{H}_{4} \mathrm{Me}-4 \\
& \text { 1d, 2d: } X=P h, Y=P h, Y^{\prime}=-O C_{6} H_{4} B r-4 \\
& \text { 1e, 2e: } X=P h, Y=P h, Y^{\prime}=-O C_{6} H_{3} M e_{2}-3,5
\end{aligned}
$$$$
\text { 1f, 2f, 3f: } X=P h, Y=P h, Y^{\prime}=-0-O
$$$$
1 \mathrm{~g}, \underline{2 \mathrm{~g}}, \underline{3 \mathrm{~g}}: X=\mathrm{Ph}, Y=P h, Y^{\prime}=
$$<smiles>Cc1cc(C)n(C)n1</smiles> 
in comparison with the observed chemical shifts for the free ligand. The spectra of $2 \mathrm{c}-2 \mathrm{~h}$ show two different resonance for the two methyl groups owing to the presence of an adjacent chiral phosphorus centre; one of these resonances is strongly shielded $(\sim 1 \mathrm{ppm})$ and appears in the region $0 \cdot 3-0.0 \mathrm{ppm}$ suggesting that these protons lie in the shielding zone of one of the phenyl groups on the phosphorus as observed in $\left[\mathrm{Mo}(\mathrm{CO})_{3}(\mathrm{MeCN})\left\{\mathrm{Ph}_{2} \mathrm{PN}\left(\mathrm{Pr}^{i}\right) \mathrm{PPh}\left(\mathrm{N}_{2} \mathrm{C}_{3} \mathrm{HMe}_{2}-3,5\right)\right\}\right]$ (Babu et al 1993).

The $\left.{ }^{13} \mathrm{C}_{\{}{ }^{1} \mathrm{H}\right\}$ NMR spectra displays four different chemical shifts for the carbonyl carbons (table 2). The carbonyls which are trans- to phosphorus atoms resonate as a doublet of doublets, whereas the cis-carbonyls display triplet resonances. The ${ }^{2} J_{P C}$ values are in the range $10-30 \mathrm{~Hz}$ and are higher for the trans carbonyls $(25-30 \mathrm{~Hz})$, with the exception of $2 \mathrm{e}$.

The ${ }^{31} \mathbf{P}\left\{{ }^{1} \mathbf{H}\right\}$ NMR spectra of the complexes exhibit a doublet of doublets owing to the non-equivalence of the phosphorus nuclei (table 3). The resonances are considerably deshielded. The extent of deshielding of the $\mathrm{PPh}_{2}$ phosphorus remains more or less the same whereas the coordination shift (Balakrishna et al 1990) $\left(\Delta \delta=\delta_{\text {complex }}-\right.$ $\delta_{\text {ligand }}$ ) (table 3) for the PYY' resonance depends upon the electronegativity of the substituents on the phosphorus which in turn determines its $\pi$-acceptor capabilities. There is no regular trend in ${ }^{2} J_{\mathrm{PP}}$ values. Diphosphazane ligands can exist as different conformers in solution (Keat et al 1981), whereas in the tetracarbonyl complexes the conformational mobility is severely restricted. Furthermore, in the complexes the $\mathbf{P}-\mathrm{P}$ coupling will be an algebraic sum of the coupling through the nitrogen as well

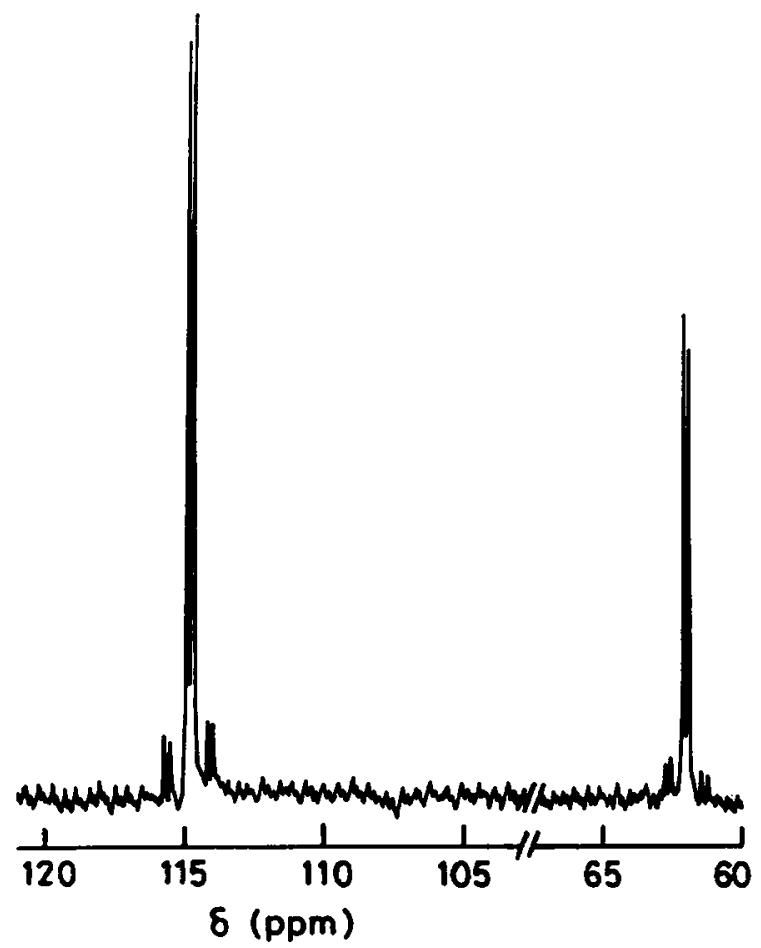

Figure 1. The ${ }^{31} \mathrm{P}$ NMR spectrum (81-02 MHz) of $\left[\mathrm{W}(\mathrm{CO})_{4}\left\{\mathrm{Ph}_{2} \mathrm{PN}(\mathrm{Pr}) \mathrm{PPh}_{(\mathrm{OC}} \mathrm{H}_{4} \mathrm{~N}-\right.\right.$ 2)\}], (3f). 
as through the metal and it is difficult to assess each of these two contributions separately.

The ${ }^{31} \mathrm{P}$ NMR spectra of the tungsten complexes $3 \mathrm{f}$ and $3 \mathrm{~g}$ display ${ }^{183} \mathrm{~W}$ satellites. The spectrum of $3 \mathrm{f}$ is shown in figure 1 . The tungsten-phosphorus coupling constants lie in the range $\overline{20} 8-256 \mathrm{~Hz}$, the more electronegative phosphorus being associated with a higher coupling constant. In spite of the presence of an additional donor atom in these diphosphazanes, the PP chelate formation is clearly favoured. This result further substantiates the earlier report that diphosphazanes with bulky substituents at the phosphorus atom show a pronounced tendency to form four-membered monometallic chelate complexes (Balakrishna et al 1991; Browning et al 1992).

\section{Acknowledgement}

The authors thank the Department of Science and Technology, New Delhi, for support.

\section{References}

Babu R P K, Krishnamurthy S S and Nethaji M 1991 Heteroatom Chem. 2477

Babu R P K, Krishnamurthy S S and Nethaji M 1993 J. Organomet. Chem. 454157

Balakrishna M S, Krishnamurthy S S and Manohar H 1991 Organometallics 102522

Balakrishna M S, Krishnamurthy S S, Murugavel R, Nethaji M and Mathews I I 1993 J. Chem. Soc., Dalton Trans. 477

Balakrishna M S, Prakasha T K, Krishnamurthy S S, Siriwardane U and Hosmane N S 1990 J. Organomet. Chem. 390203

Balakrishna M S, Reddy V S, Krishnamurthy S S, Nixon J F and Burckett St. Laurent J C T R 1994 Coord. Chem. Rev. 1291

Browning C S, Farrar D H and Frankal D C 1992 Acta Crystallogr. C48 806

Colquhoun I G and McFarlane W 1977 J. Chem. Soc., Dalton Trans. 1674

Cotton F A and Kraihanzel C S 1962 J. Am. Chem. Soc. 844432

Cross R H, Green T H and Keat R $1976 \mathrm{~J}$. Chem. Soc., Dalton Trans. 141424

Darensbourg D J and Kump R L 1978 Inorg. Chem. 172680

Field J S, Haines R J, Stewart M W, Sundermeyer J and Woollam S F 1993 J. Chem. Soc., Dalton Trans. 947

Keat R, Muir L M, Muir K W and Rycroft D S 1981 J. Chem. Soc., Dalton Trans. 2192

King R B 1980 Acc. Chem. Res. 13243

King R B and Lee T W 1982 Inorg. Chem. 21319

Mague $J$ T and Lin Z 1992 Organometallics 114139

Rossi R, Marchi A, Marvelli L, Magon L, Peruzzini M, Casellato U and Graziani R 1993 J. Chem. Soc., Dalion Trans. 723

Shriver D F and Drezdzon M A 1986 The manipulation of air sensitive compounds 2nd edn (New York: Wiley-Interscience) 